be approximately $0^{\circ}$ if the Mo atom were bonded solely to the nitrogen lone pair or $90^{\circ}$ if it were bonded to the imine $\pi$ bond.

(8) Several examples of multiple isocyanide insertion rearrangements have been reported previously 6,9

(9) S. Otsuka, A. Nakamura, T. Yoshida, M. Naruto, and K. Ataka, J. Am. Chem. Soc., 95, 3180 (1973); S. Otsuka, A. Nakamura, and T. Yoshida, ibid., 91, 7196 (1969).

(10) Satisfactory elemental analyses have been obtained.

(11) Y. Yamamoto and H. Yamazaki, J. Organomet. Chem., 24, 717 (1970). (12) W. H. Baddley, Inorg. Chim. Acta, 2, 7 (1968).

Richard D. Adams,* Daniel F. Chodosh Chemistry Department, Yale University New Haven, Connecticut 06520

Received February 26, 1976

\section{Novel Chiral Triorganotin Halides. Stabilization of Optically Active Tin Centers by Intramolecular Coordination}

Sir:

Contrary to the high optical stability of tetraorganotin compounds ${ }^{1}$ triorganotin halides are configurationally unstable. ${ }^{2,3}$ In the presence of nucleophiles the RR' $R^{\prime \prime} S n X$ enantiomers isomerize either via formation of penta- or hexacoordinate tin intermediates which are stereochemically nonrigid or via an $\mathrm{SN} 2$ type mechanism which leads to direct inversion of configuration. ${ }^{4}$

We report here that chiral triorganotin halides with high optical stability may be obtained by rendering the tin atom pentacoordinate by intramolecular coordination so that stereoisomerization pathways are blocked.

Recently, we have reported ${ }^{5}$ a facile one-step synthesis for (2- $\left.\mathrm{Me}_{2} \mathrm{NCH}_{2} \mathrm{C}_{6} \mathrm{H}_{4}\right) \mathrm{R}_{2} \mathrm{SnBr}$ compounds $(1, \mathrm{R}=\mathrm{Me} ; \mathbf{2}, \mathrm{R}=$ $\mathrm{Ph})$. An $\mathrm{x}$-ray investigation has shown that the tin atom in 2 is pentacoordinate as a result of intramolecular $\mathrm{Sn}-\mathrm{N}$ coordination. 6

We have now synthesized ${ }^{7}\left(2-\mathrm{Me}_{2} \mathrm{NCH}_{2} \mathrm{C}_{6} \mathrm{H}_{4}\right) \mathrm{MePhSnBr}$, 3 , in which the tin atom is a chiral center. The $\mathrm{Me}_{2} \mathrm{NCH}_{2}$ ligand, present in this structure, allows the study by NMR spectroscopy of the configurational stability of the chiral tin center as well as of the occurrence of intramolecular Sn-N coordination. 8

Figure 1 shows the NMR spectrum of 3 in toluene- $d_{8}$ at 10,30 , and $123^{\circ} \mathrm{C}$. The benzylic protons $\left(25^{\circ} \mathrm{C} ; ;^{9} \mathrm{AB}, \delta 3.02\right.$ and $2.81 \mathrm{ppm}$ ) are anisochronous up to $123^{\circ} \mathrm{C}^{10}(\Delta \delta$ decreases from $21 \mathrm{~Hz}\left(0^{\circ} \mathrm{C}\right)$ to $\left.15.5 \mathrm{~Hz}\left(123^{\circ} \mathrm{C}\right)\right)$ and thus diastereotopic. Consequently, up to $123^{\circ} \mathrm{C}$ the rate at which the absolute configuration of the chiral tin atom inverts $(\mathrm{Sn} \rightleftarrows \pi \mathrm{Z}$ ) is slow on the NMR timescale, because it is only by this inversion process that the benzylic protons become enantiotopic and isochronous.

The observation below $30^{\circ} \mathrm{C}$ of two singlets for the $\mathrm{NMe}$ protons at $\delta 1.50$ and $1.28 \mathrm{ppm}$ which coalesce above $30^{\circ}$ to one singlet at $1.39 \mathrm{ppm}$ is interpreted in terms of rate determining intramolecular $\mathrm{Sn}-\mathrm{N}$ coordination. Pyramidal inversion at nitrogen in $N, N$-dialkylbenzylamines is a low energy process which has an estimated barrier lower than $6 \mathrm{kcal} /$ mol. ${ }^{11}$ Consequently, inversion at nitrogen (rate constant $k_{\mathrm{i}}$ ) takes place in the tetracoordinate tin conformer. In the pentacoordinate tin conformer $\mathrm{Sn}-\mathrm{N}$ coordination (rate constant $k_{\mathrm{c}}$ ) makes a stable prochiral assembly of the $\mathrm{NMe}_{2}$ group and renders the NMe groups diastereotopic and thus anisochronous because of the dissymmetry at tin. Two processes can be envisaged by which the NMe groups can become homotopic (enantiotopic): (i) by inversion of configuration at tin in the pentacoordinate conformer (rate constant $k_{\mathrm{r}}{ }^{\prime}$ ), i.e., without prior $\mathrm{Sn}-\mathrm{N}$ bond dissociation (vide infra), and (ii) by $\mathrm{Sn}-\mathrm{N}$, bond dissociation (rate constant $k_{\mathrm{d}}$ ) followed by inversion at $\mathrm{N}$ with concomitant $180^{\circ}$ rotation about the $\mathrm{CH}_{2}-\mathrm{N}$ bond and
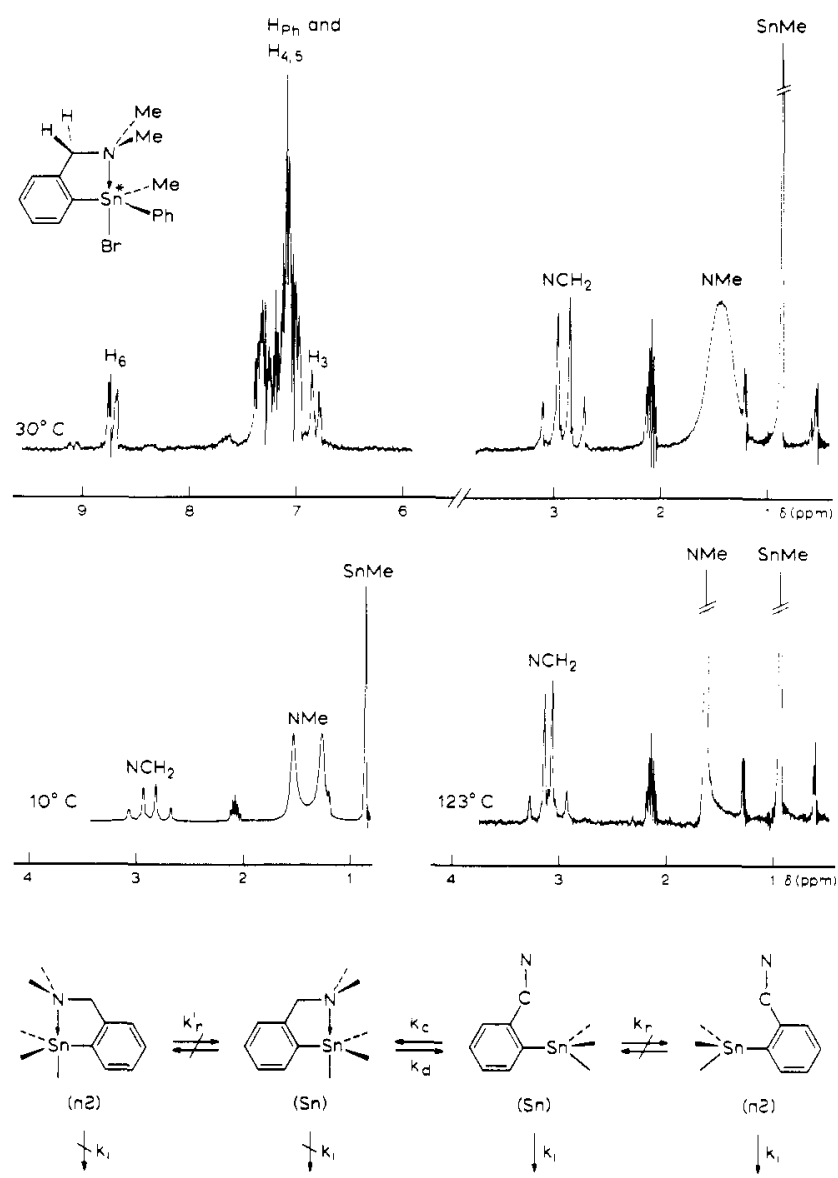

Figure 1. ${ }^{1} \mathrm{H}$ NMR spectrum $(100 \mathrm{MHz})$ of $\left(2-\mathrm{Me}_{2} \mathrm{NCH}_{2} \mathrm{C}_{6} \mathrm{H}_{4}\right)$ $\left(\mathrm{C}_{6} \mathrm{H}_{5}\right) \mathrm{MeSnBr}$ in toluene- $d_{8}$ (resonances at $\delta 2.1$ and $7.1 \mathrm{ppm}$ are due to hydrogen containing sites of the solvent). Only the high field part of the spectra recorded at $10^{\circ}$ and $123^{\circ} \mathrm{C}$ is shown

re-formation of the $\mathrm{Sn}-\mathrm{N}$ bond. The latter mechanism accounts for the observed dynamic NMR pattern whereas the observation that the $\mathrm{NCH}_{2}$ and NMe proton resonance patterns coalesce at different rates excludes the former mechanism.

External ligands such as $\mathrm{PPh}_{3}, \mathrm{NPh}_{3}, \mathrm{DABCO}$, and pyridine, which readily cause inversion of configuration in other chiral triorganotin halides,,$^{1,2}$ do not interact with the tin atom in $3^{12}$ as can be concluded from the absence of any effect on the resonance patterns or on the $T_{\mathrm{c}}$ value of the NMe resonances. However, it has been shown that in (2$\left.\mathrm{Me}_{2} \mathrm{NCH}_{2} \mathrm{C}_{6} \mathrm{H}_{4}\right)_{2} \mathrm{MeSnBr}, 4,{ }^{13}$ which contains two internal ligands, intramolecular exchange does take place. The NMR of 4 at $-50^{\circ} \mathrm{C}$ shows two sets of diastereotopic $\mathrm{NCH}_{2}$ protons (two $\mathrm{AB}$ patterns: $\Delta \delta, 1.48 \mathrm{ppm}$, irradiation at $2.7 \mathrm{ppm}$ resulted in a singlet at $4.27 \mathrm{ppm} ; \Delta \delta_{2} 0.58 \mathrm{ppm}$ ), two multiplets for $\mathrm{H}_{6}$ at $\delta 8.85$ and $7.20 \mathrm{ppm}$, and two sets of $\mathrm{NMe}$ protons (two singlets at $\delta 1.34$ and $1.52 \mathrm{ppm}$ for diastereotopic NMe groups and one singlet at $1.62 \mathrm{ppm}$ for homotopic $\mathrm{NMe}$ groups) (Figure 2). This pattern is compatible with a pentacoordinate structure at low temperature containing one $\mathrm{C}, \mathrm{N}$ - and one C-bonded 2- $\mathrm{Me}_{2} \mathrm{NCH}_{2} \mathrm{C}_{6} \mathrm{H}_{4}$ group. In the temperature range $-50^{\circ}$ to $20^{\circ} \mathrm{C}$ the two sets of resonance patterns for the 2 $\mathrm{Me}_{2} \mathrm{NCH}_{2} \mathrm{C}_{6} \mathrm{H}_{4}$ groups coalesce to give an averaged multiplet for $\mathrm{H}_{6}$ at $\delta 8.12 \mathrm{ppm}$, one broadened singlet for the $\mathrm{NMe}$ protons at the position of homotopic NMe groups while the two sets of diastereotopic $\mathrm{NCH}_{2}$ protons coalesce to an averaged $\mathrm{AB}$ pattern with $\Delta \delta 0.58 \mathrm{ppm}$. The two types of $\mathrm{Me}_{2} \mathrm{NCH}_{2} \mathrm{C}_{6} \mathrm{H}_{4}$ groups observable below $-50^{\circ} \mathrm{C}$ have now become equivalent on the NMR timescale by an intramolecular exchange process (pentacoordinate $\mathrm{Sn} \rightleftarrows$ pentacoordinate 


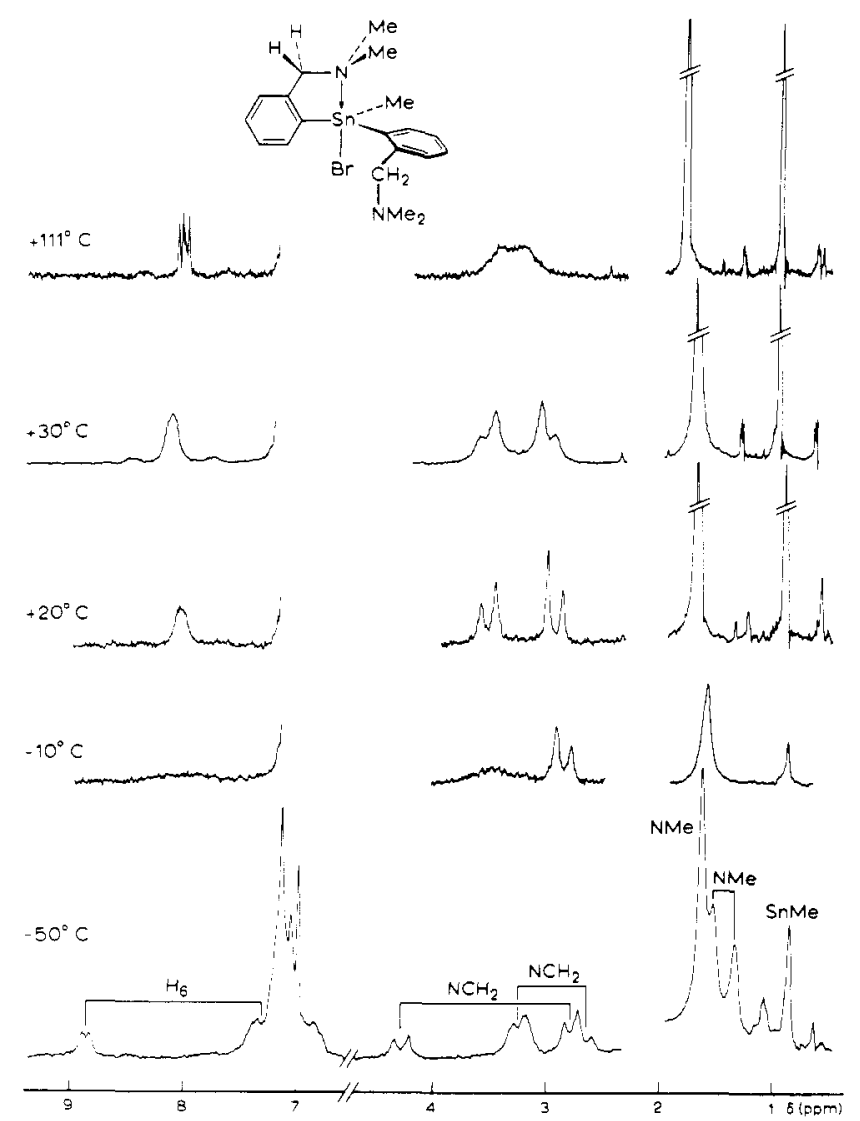

Figure 2. ${ }^{1} \mathrm{H}$ NMR spectrum $(100 \mathrm{MHz})$ of $\left(2-\mathrm{Me}_{2} \mathrm{NCH}_{2} \mathrm{C}_{6} \mathrm{H}_{4}\right)_{2} \mathrm{MeSnBr}$ in toluene- $d_{8}$.

Scheme I
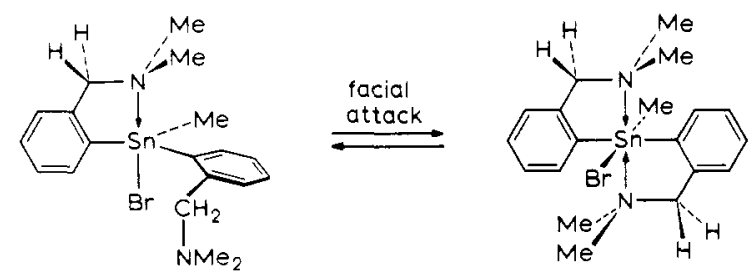

$(\mathrm{Sn})$
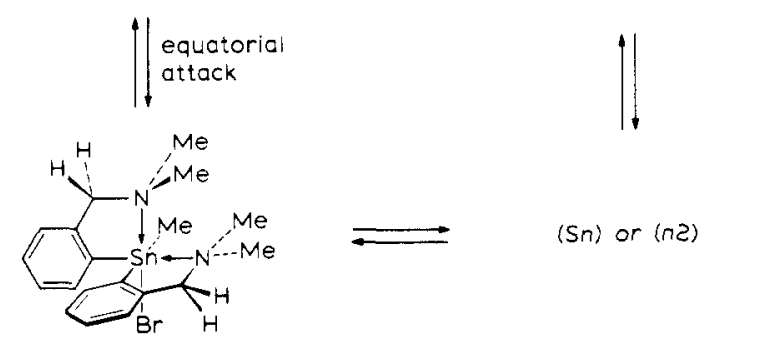

$(S n)$ or $(n 2)$

$\left.\mathrm{Sn}^{\prime}\right)$ which presumably involves a hexacoordinate transition state or intermediate, e.g., Scheme I. Above $20^{\circ} \mathrm{C}$ the rate constants for both the dissociation process (pentacoordinate $\mathrm{Sn} \rightleftarrows$ tetracoordinate $\mathrm{Sn}$ ) and the inversion process at nitrogen increase as is reflected in a sharpening of the $\mathrm{H}_{6}$ multiplet as well as in a decrease of the $\Delta \delta$ value of the anisochronous $\mathrm{CH}_{2}$ protons. ${ }^{14}$

We ascribe the high configurational stability of these triorganotin halides to a combination of factors. Complex formation with external Lewis bases, believed to be the first step in the stereoisomerization process of triorganotin halides, cannot compete with intramolecular coordination. ${ }^{15}$ Furthermore, stereoisomerization routes in the pentacoordinate conformer, ${ }^{16}$ e.g., by a Berry pseudorotation mechanism, are energetically unfavorable in view of (i) the strong site prefer- ence of the electronegative bromine and nitrogen atoms for axial positions ${ }^{17}$ and (ii) the geometric constraints of the five-membered chelate ring (N-Sn-C, 75.3 $\left.{ }^{\circ}\right) .^{6}$ Study of the corresponding (2- $\mathrm{Me}_{2} \mathrm{NCH}_{2} \mathrm{C}_{6} \mathrm{H}_{4} \mathrm{CH}_{2}$ ) $\mathrm{MePhSnBr}, 5$, 18 for which intramolecular $\mathrm{Sn}-\mathrm{N}$ coordination leads to a sixmembered chelate ring ${ }^{19}$ supports this idea.

The NMR spectrum of 5 in toluene- $d_{8}$ shows at room temperature isochronous resonances for the $-\mathrm{CH}_{2} \mathrm{Sn}(\delta 4.07 \mathrm{ppm}$, averaged $\left.{ }^{2} J_{\mathrm{Sn}-\mathrm{H}}=86 \mathrm{~Hz}\right),-\mathrm{CH}_{2} \mathrm{~N}(\delta 3.91 \mathrm{ppm})$, and $\mathrm{NMe}$ $(\delta 1.41 \mathrm{ppm})$ protons. On cooling the NMe groups $\left(T_{\mathrm{c}} \approx-37\right.$ $\left.{ }^{\circ} \mathrm{C} ; \Delta \delta 38 \mathrm{~Hz}\right)$ and $\mathrm{CH}_{2} \mathrm{Sn}$ and $\mathrm{CH}_{2} \mathrm{~N}$ protons $\left(T_{\mathrm{c}} \approx 0{ }^{\circ} \mathrm{C} ; \Delta \delta\right.$ 15 and $9 \mathrm{~Hz}$, respectively) become diastereotopic and thus anisochronous at about the same rate. It is only in the pentacoordinate conformer that inversion of the absolute configuration at the tin atom is reflected simultaneously in the resonance patterns of these three prochiral groupings. Ligand site exchange is now a lower energy process because of the lower constraints of a six-membered chelate ring containing two $\mathrm{sp}^{3}$ carbon atoms as compared with the five-membered chelate rings of 3 and 4 .

Acknowledgment. We thank Miss N. Natan and Mr. J. T. B. H. Jastrzebski for preparative assistance and Mr. J. W. Marsman for helpful discussions.

\section{References and Notes}

(1) M. Gielen, M. R. Barthels, M. de Clercq, C. Dehouck, and G. Mayence, J. Organomet. Chem., 34, 315 (1972); M. Lequan and F. Meganem, ibid., 94, C 1 (1975); M. Gielen and H. M. Jamai, Bull. Soc. Chim. Belg., 84, 197 (1975).

(2) G. J. D. Peddle and G. Redl, J. Chem. Soc., Chem. Commun., 626 (1968); C. E. Holloway, S. A. Kandil, and I. M. Walker, J. Am. Chem. Soc., 94, 4027 (1972). For the influence of bulky substituents on the optical stability of organotin compounds, see M. Gielen and H. M. Jamai, Bull. Soc. Chim. Belg., 84, 1037 (1975).

(3) Recently, monoorganotin compounds containing a hexacoordinate chira tin center have been shown to have low optical stability, see N. Serpone and K. A. Hersh, Inorg. Chem. 13, 2901 (1974); K. D. Bos, E. J. Bulten, and J. G. Noltes, J. Organomet. Chem., 99, 397 (1975).

(4) M. Gielen and H. M. Jamai, J. Organomet. Chem., 91, C 33 (1975)

(5) G. van Koten, C. A. Schaap, and J. G. Noltes, J. Organomet. Chem., 99, $157(1975)$.

(6) G. van Koten, J. G. Noltes, and A. L. Spek, J. Organomet. Chem., in press.

(7) Obtained in $90 \%$ yield from the $1 / 1$ reaction of $\mathrm{Me}_{2} \mathrm{NCH}_{2} \mathrm{C}_{6} \mathrm{H}_{4}-\mathrm{Cu}$, 6 , or $-\mathrm{LI}, 7$, with $\mathrm{MePhSnBr}_{2}$ according to the procedures described in ref $5 . \mathrm{Mp}$ $121-125^{\circ} \mathrm{C}$, monomeric in benzene (osmometry) concentration independent, 432; $\mathrm{C}_{16} \mathrm{H}_{20}$ BrNSn calcd. 425

(8) We have used the $\mathrm{Me}_{2} \mathrm{NCH}_{2}$ ligand as a probe for the detection of dissymmetry in the metal core of ary/metal $1 \mathrm{~b}$ cluster compounds.

(9) Analysis of the AB part of the ABX spectrum due to ${ }^{117} \mathrm{Sn}$ and ${ }^{119} \mathrm{Sn}$. isotopes which allows the determination of $a^{4} J_{S n-H}$ is underway; see also Holloway et al. ${ }^{2}$

(10) I. e., the racemization process has an activation energy barrier much higher than $100 \mathrm{~kJ} \mathrm{~mol}^{-1}$ which should allow separation of the enantiomers.

(11) E.g., H. Kessler, Angew. Chem., 82, 237 (1970)

(12) This conclusion is also supported by the observation that ${ }^{2} \mathrm{~J}_{\mathrm{Sn}_{-}-\mathrm{CH}_{3}}=$ $68.2 / 65.5 \mathrm{~Hz}$ and ${ }^{3} \mathrm{~J}_{\mathrm{Sn}-\mathrm{H}_{6}}=70 \mathrm{~Hz}$ are solvendependent whereas the chemical shift values of various protons in 3 are very solvent dependent. i.e., the series toluene- $d_{8} /$ pyridine- $d_{5} / \mathrm{CCl}_{4}(\delta \mathrm{ppm})$ : NMe, 1.45/1.87/2.00: CH., the series toluene- $d_{8} /$ pyridine- $d_{5} / \mathrm{CCl}_{4}(\delta \mathrm{ppm})$ : NMe, $1.45 / 1.87$ and $2.81 / 3.39$ and $3.38 / 3.50$ and $3.37\left(\mathrm{~J}_{\mathrm{gem}}=14 \mathrm{~Hz}\right)$; $\mathrm{CH}_{3} \mathrm{Sn}, 0.87 / 1.16 / 1.00$ and $\mathrm{H}_{6}, 8.72 / 8.76 / 8.30$. The latter data show that preferential solvent-solute interactions occur at the site of the intramolecular ligand $\mathrm{CH}_{2} \mathrm{NMe}_{2}{ }^{5}$

(13) Obtained in $60 \%$ yield from the addition in $t / 1$ molar ratio of $\mathrm{Me}_{2} \mathrm{SnBr}_{2}$ to 7 as well as from the $1 / 1$ reaction of $\left(2-\mathrm{Me}_{2} \mathrm{NCH}_{2} \mathrm{C}_{6} \mathrm{H}_{4}\right)_{2} \mathrm{Me}_{2} \mathrm{Sn}$ with $\mathrm{Me}_{2} \mathrm{SnBr}_{2} . \mathrm{Mp} 142-144{ }^{\circ} \mathrm{C}$, monomeric in benzene (osmometry) found, 484; $\mathrm{C}_{19} \mathrm{H}_{27} \mathrm{BrN}_{2} \mathrm{Sn}$ calcd, 481.

(14) The benzylic carbn atoms in the tetracoordinate tin conformer are not $\mathrm{C}_{2}$ centers and thus the benzylic protons remain diastereotopic.

(15) The occurrence of intramolecular $\mathrm{Sn}-\mathrm{N}$ coordination in the tetracoordinate tin conformer of 3 can be viewed as the first step of an SN2 type substitution process at tin. Continuation of this process beyond the TBP configuration resulting in $\mathrm{Sn}-\mathrm{Br}$ bond dissociation, would require opening of the $\mathrm{N}-\mathrm{Sn}-\mathrm{C}$ angle from about $75.3^{\circ} 6$ to formally $109^{\circ}$. This is unlikely in view of the geometric constraints of the chelate ring. However, in $22,6-\left(\mathrm{Me}_{2} \mathrm{NCH}_{2}\right)$ $\mathrm{C}_{6} \mathrm{H}_{3}$ i MePhSnBr the $\mathrm{Sn}-\mathrm{Br}$ bond is dissociated because the $\mathrm{C}_{3} \mathrm{Sn}$ cationic state is stabilized by $\mathrm{Sn}-\mathrm{N}$ coordination of the two $\mathrm{Me}_{2} \mathrm{NCH}_{2}$ ligands resulting in a TBP configuration around tin.

(16) E. L. Muetterties and R. A. Schunn, Q. Rev., Chem. Soc, 20, 245 (1966); G. M. Whitesides and H. L. Mitchell, J. Am. Chem. Soc., 91, 5384 (1969); F. H. Westheimer, Acc. Chem. Res., 1, 70 (1968); R. R. Holmes, ibid., 5, 296 (1972); J. R. Shapley and J. A. Osborn, Ibid., 6, 305 (1973).

(17) B. Y. K. Ho and J. J. Zuckerman, J. Organomet. Chem., 49, 1 (1973)

(18) Isolated in $30 \%$ yield from $1 / 1$ reaction of $2-\mathrm{Me}_{2} \mathrm{NCH}_{2} \mathrm{C}_{6} \mathrm{H}_{4} \mathrm{CH}_{2} \mathrm{Li}$ with

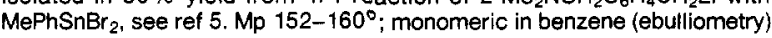


found, $439 ; \mathrm{C}_{17} \mathrm{H}_{22} \mathrm{BrNSn}$ calcd, 438

19) This six-membered ring is puckered both at the $\mathrm{CH}_{2} \mathrm{Sn}$ as well as at the $\mathrm{SnN}\left(\mathrm{Me}_{2}\right) \mathrm{CH}_{2}$ part. In the pentacoordinate $\left\{5-\mathrm{MeO}-8-\mathrm{Me}_{2} \mathrm{NCM}_{2}\right.$ naphthyl MeRSnBr ( $R=M e$ or $P h$ ) compounds puckering is restricted to the $\mathrm{SnN}\left(\mathrm{Me}_{2}\right) \mathrm{CH}_{2}$ part which results in two different conformations for the six-membered chelate ring. Both conformations can be frozen out on the NMR timescale below $-30^{\circ} \mathrm{C}$.

Gerard van Koten,* Jan G. Noltes Institute for Organic Chemistry TNO Utrecht, The Netherlands Received April 1, 1976

\section{Synthesis of Transition Metal Formyl Compounds by Nucleophilic Attack of Hydride on Coordinated $\mathrm{CO}$}

Sir:

There is renewed interest in the conversion of coal to gaseous and liquid fuels. These conversions can be accomplished by the reaction of coal with water to give a 1:1 mixture of $\mathrm{CO}: \mathrm{H}_{2}$, which can subsequently be passed over various heterogeneous transition metal catalysts to give methane or methanol or (via the Fischer-Tropsch reaction) gasoline. ${ }^{1-3}$ Little is known about the mechanism of these reductions, but transition metal formyl complexes may well be important intermediates in the initiation step for the catalytic reduction of $\mathrm{CO}$ by $\mathrm{H}_{2}$. However, attempts to obtain evidence for the intermediacy of metal formyl complexes in the reactions of metal carbonyl hydrides have uniformly met with failure. ${ }^{4}$ Our interest in the mechanism of the Fischer-Tropsch reaction and in the development of a homogeneous catalyst for the reduction of $\mathrm{CO}$ has led us to undertake a study of the synthesis and reactions of metal formyl complexes. The only previously reported metal formyl complex, $\left[\left(\mathrm{Ph}_{3} \mathrm{P}\right)_{2} \mathrm{~N}\right]^{+}(\mathrm{CO})_{4} \mathrm{FeCHO}^{-}$, 1, was prepared by Collman and Winter in 1973 by the reaction of $\mathrm{Na}_{2} \mathrm{Fe}(\mathrm{CO})_{4}$ with acetic formic anhydride. ${ }^{7}$ Here we report (1) a new synthesis of metal formyl complexes from the reactions of metal carbonyl compounds with trialkoxyborohydrides, (2) the isolation of a second stable metal formyl complex, $\left[\mathrm{Et}_{4} \mathrm{~N}\right]^{+}$ trans $-\left[(\mathrm{PhO})_{3} \mathrm{P}\right](\mathrm{CO})_{3} \mathrm{FeCHO}^{-}, 2$, and (3) the observation of a number of unstable metal formyl complexes.

The reactions of borohydrides with transition metal carbonyl compounds have been used to facilitate the substitution of one or more ligands for $\mathrm{CO},{ }^{8-10}$ and to synthesize certain group 6 dinuclear metal carbonyl hydrides. ${ }^{11,12}$ We have found that the reaction of $\mathrm{Na}^{+} \mathrm{HB}\left(\mathrm{OCH}_{3}\right)_{3}{ }^{-}$or $\mathrm{K}^{+} \mathrm{HB}(\mathrm{O}-i \text {-Pr })_{3}{ }^{-13}$ with various metal carbonyl compounds leads to transition metal formyl compounds according to eq 1 . Reaction of $\mathrm{Na}^{+} \mathrm{H}-$

$$
\begin{gathered}
\mathrm{HB}(\mathrm{OR})_{3}+\mathrm{L}_{x} \mathrm{M}(\mathrm{CO}) \rightarrow \mathrm{B}(\mathrm{OR})_{3}+\mathrm{L}_{x} \overline{\mathrm{M}}_{\mathrm{H}} \\
\mathrm{L}=\mathrm{PPh}_{3}, \mathrm{P}(\mathrm{OPh})_{3}, \mathrm{CO} \\
\mathrm{R}=-\mathrm{CH}_{3,}, \mathrm{CH}\left(\mathrm{CH}_{3}\right)_{2}
\end{gathered}
$$

$\mathrm{B}\left(\mathrm{OCH}_{3}\right)_{3}-$ with $\mathrm{Fe}(\mathrm{CO})_{5}$, followed by cation exchange with $\left[\left(\mathrm{Ph}_{3} \mathrm{P}\right)_{2} \mathrm{~N}\right]^{+} \mathrm{Cl}^{-}$, gives $\left[\left(\mathrm{Ph}_{3} \mathrm{P}\right)_{2} \mathrm{~N}\right]^{+}(\mathrm{CO})_{4} \mathrm{FeCHO}^{-}, \mathbf{1}$, in $80-90 \%$ yield by NMR analysis ${ }^{14}$ and in $39 \%$ isolated yield, $\mathrm{mp} 122-132{ }^{\circ} \mathrm{C}$ (sealed tube) dec. ${ }^{15}$ The infrared spectrum and $' \mathrm{H}$ and ${ }^{13} \mathrm{C}$ NMR spectrum of 1 prepared from $\mathrm{Fe}(\mathrm{NO})_{5}$ and $\mathrm{Na}+\mathrm{HB}\left(\mathrm{OCH}_{3}\right)_{3}-16$ were identical with the spectra of a sample of 1 prepared from $\mathrm{Na}_{2} \mathrm{Fe}(\mathrm{CO})_{4}$ and acetic formic anhydride. ${ }^{7}$ The formyl proton characteristically appears at very low field, $\delta 14.95$, in the ${ }^{1} \mathrm{H}$ NMR; similarly, the formyl carbon appears at characteristically low field, $\delta 270.5$, in the ${ }^{13} \mathrm{C}$ NMR spectrum. Reaction of 1 (prepared from $\mathrm{Na}^{+} \mathrm{H}-$ $\mathrm{B}\left(\mathrm{OCH}_{3}\right)_{3}^{-}$and $\left.\mathrm{Fe}(\mathrm{CO})_{5}\right)$ with $\mathrm{HCl}$ in THF gives formal- dehyde as previously reported. ${ }^{7,17} \mathrm{~A}$ THF solution of 1 reacts with $\mathrm{HCl}$ in the presence of $\mathrm{Ph}_{3} \mathrm{P}$ to give $(\mathrm{CO})_{4} \mathrm{FePPh}_{3}(57 \%)$ and $(\mathrm{CO})_{3} \mathrm{Fe}\left(\mathrm{PPh}_{3}\right)_{2}(20 \%)$; similar results were reported in the $\mathrm{NaBH}_{4}$ "facilitated" substitution of $\mathrm{Fe}(\mathrm{CO})_{5}$ by $\mathrm{PPh}_{3}$, although iron formyl species were not proposed for these reactions. $^{8}$

The reaction of trialkoxyborohydrides as a hydride source with metal carbonyl compounds is an excellent organometallic synthetic method. The rapidity and ease of the procedure, along with the ability to obtain adequate yields, make the method quite useful. Moreover, this procedure can be extended to the synthesis of metal formyl compounds from systems other than $\mathrm{Fe}(\mathrm{CO})_{5}$, whereas in our hands the reaction of acetic formic anhydride with metal carbonyl anions could not. Reaction of $\mathrm{CH}_{3} \mathrm{C}(\mathrm{O}) \mathrm{OC}(\mathrm{O}) \mathrm{H}$ with $\mathrm{C}_{5} \mathrm{H}_{5} \mathrm{Fe}(\mathrm{CO})_{2}{ }^{-}, \mathrm{Cr}$ $(\mathrm{CO})_{5}^{2-},\left(\mathrm{Ph}_{3} \mathrm{P}\right) \mathrm{Mn}(\mathrm{CO})_{4}{ }^{-}$, and $\left(\mathrm{Ph}_{3} \mathrm{P}\right)_{2} \mathrm{Mn}(\mathrm{CO})_{3}-$ produced no products with ${ }^{\mathrm{l}} \mathrm{H}$ NMR resonances below $\delta 10$ expected for metal formyl compounds. However, reaction of $\mathrm{Na}+\mathrm{HB}\left(\mathrm{OCH}_{3}\right)_{3}{ }^{-}$with the appropriate metal carbonyl compound in THF in a sealed NMR tube led, in many cases, to the appearance of characteristic formyl ${ }^{l} \mathrm{H}$ NMR resonances below $\delta 10$. We now have NMR evidence for the formation of metal formyl compounds from $\mathrm{Cr}(\mathrm{CO})_{6}(\delta 15.2, \mathrm{~s}),{ }^{18}$ $\mathrm{W}(\mathrm{CO})_{6}(\delta 15.9, \mathrm{~s}),(\mathrm{CO})_{5} \mathrm{CrPPh}_{3}(\delta 15.3, \mathrm{~s}),(\mathrm{CO})_{5} \mathrm{WPPh}_{3}$ $(\delta 15.8, \mathrm{~s})$, and $(\mathrm{CO})_{4} \mathrm{FePPh}_{3}(\delta 15.5, \mathrm{~d}, J=24 \mathrm{~Hz}){ }^{19}$ Quantitative NMR studies on several of the above systems indicated that the extent of the reaction producing the desired metal formyl compound was generally quite low $(<10 \%),{ }^{14}$ and as a result we tried analogous reactions of $\mathrm{K}^{+} \mathrm{HB}(\mathrm{O}-i \text { - } \mathrm{Pr})_{3}-20$ with several metal carbonyl compounds in an attempt to increase the extent of reaction by using a more reactive hydride. ${ }^{13 b} \mathrm{We}$ found that $\mathrm{Cr}(\mathrm{CO})_{6}$ reacts with $\mathrm{K}^{+} \mathrm{HB}(\mathrm{O}-i-\mathrm{Pr})_{3}{ }^{-}$ to give a maximum $76 \%$ conversion to the formyl compound in $25 \mathrm{~min}$ at ambient temperature; ${ }^{14}$ the product formyl complex, $\mathrm{K}^{+}(\mathrm{CO})_{5} \mathrm{CrCHO}^{-}$, is half decomposed in an additional $40 \mathrm{~min}$. In contrast, the reaction of $\operatorname{Cr}(\mathrm{CO})_{6}$ with $\mathrm{Na}{ }^{+} \mathrm{HB}\left(\mathrm{OCH}_{3}\right)_{3}{ }^{-}$gives a maximum of $4 \%$ of the metal formyl after $25 \mathrm{~min}$ at ambient temperature. ${ }^{14}$ The reaction of $\mathrm{K}^{+} \mathrm{HB}(\mathrm{O}-i \text {-Pr })_{3}^{-}$with $\mathrm{W}(\mathrm{CO})_{6}$ and $(\mathrm{CO})_{4} \mathrm{FePPh}_{3}$ gives qualitatively similar results.

We have been able to isolate and characterize the second known compound of the metal formyl class by the reaction of a sixfold excess of $\mathrm{K}^{+} \mathrm{HB}(\mathrm{O}-i \text { - } \mathrm{Pr})_{3}{ }^{-}$with $(\mathrm{CO})_{4} \mathrm{FeP}(\mathrm{OPh})_{3}$ in THF. ${ }^{15}$ Cation exchange of the resulting potassium salt with $\left[\mathrm{Et}_{4} \mathrm{~N}\right]^{+} \mathrm{Br}^{-}$and $1 \mathrm{~N} \mathrm{NaOH}$ gave $\left[\mathrm{Et}_{4} \mathrm{~N}\right]^{+}$trans $\left[(\mathrm{PhO})_{3} \mathrm{P}\right](\mathrm{CO})_{3} \mathrm{FeCHO}^{-}, 2$, as a light tan powder in $64 \%$ yield, mp $40-55^{\circ} \mathrm{C}$ (sealed tube) dec. ${ }^{21}$ Solutions of 2 are rapidly oxidized by air and undergo thermal decomposition at $65^{\circ}$ over several hours. 2 shows spectral properties fully consistent with its proposed structure: ${ }^{1} \mathrm{H}$ NMR (acetone- $d_{6}$ ) $\delta 1.30\left(\mathrm{tt}, J=7.7 \mathrm{~Hz}, J_{\mathrm{NH}}=1.5 \mathrm{~Hz}, 12 \mathrm{H}, \mathrm{NCH}_{2} \mathrm{CH}_{3}\right), 3.40$ $\left(\mathrm{q}, J=7.7 \mathrm{~Hz}, 8 \mathrm{H}, \mathrm{NCH}_{2} \mathrm{CH}_{3}\right), 6.8-7.8\left(\mathrm{~m}, 15 \mathrm{H}, \mathrm{C}_{6} \mathrm{H}_{5}\right)$, 14.82 (d, $J_{\mathrm{PH}}=44.4 \mathrm{~Hz}, 1 \mathrm{H}, \mathrm{FeCHO}$ ); ir (THF) $2515 \mathrm{~cm}^{-1}$ $\left(\mathrm{w}\right.$, aldehyde $\left.\mathrm{C}-\mathrm{H}^{22}\right), 1960(\mathrm{~m}, \mathrm{MC} \equiv \mathrm{O}), 1872$ (vs, $\mathrm{MC} \equiv \mathrm{O}^{23}$ ), 1584 ( $\mathrm{m}$, formyl $\mathrm{C}=\mathrm{O}$ ).

This new synthesis of metal formyl complexes will enable us to study the kinetic stability of metal formyl complexes, the equilibrium between metal hydrides and metal formyl complexes, and the reaction of metal formyl compounds with hydrogen and other reducing agents.

Acknowledgment. Support from the National Science Foundation and from the donors of the Petroleum Research Fund, administered by the American Chemical Society, is gratefully acknowledged.

Supplementary Material Available: Experimental procedures (2 pages). Ordering information is given on any current masthead page. 